\title{
Prikaz kretanja izbjeglica preko teritorija Republike Hrvatske u dnevnom tisku (Večernji list, Jutarnji list, 24 sata)
}

Suzana Peran*

suzana.peran@unicath.hr

Anđelka Raguž**

araguz@hrstud.hr https://doi.org/10.31192/np.17.1.2

UDK: 314.151.3-054.73(497.5)

070:314.151.3-054.73(497.5)

Izvorni znanstveni rad / Original scientific paper

Primljeno: 8. prosinca 2018.

Prihvaćeno: 7. veljače 2019.

Cilj je ovoga rada istražiti koliko su i kako hrvatske dnevne novine - Jutarnji list, Večernji list i 24sata - izvještavale o izbjegličkome valu i prolasku izbjeglica kroz Republiku Hrvatsku od rujna 2015. do travnja 2017. godine. Istraživali smo $i$ način izvještavanja kroz prisutnost novinarskog stava, možebitno etiketiranje izbjeglica, kao i kršenje etičnih normi u izvještavanju. Pozornost je posebno posvećena odnosu naslova i teksta objava. U provedenom kvantitativnom istraživanju, s jedne su strane odbačene početne pretpostavke da izvještavanje o izbjeglicama uključuje senzacionalistički pristup temi, da se izbjeglice $i$ (e) migrante medijski prikazuje kao opasne za gospodarsku stabilnost zemlje i kao potencijalnu terorističku prijetnju te da istodobno novinski prilozi apeliraju na emocije čitatelja. S druge je strane istraživanje potvrdilo kako se medijski djelatnici pri izvještavanju o izbjeglicama nisu pridržavali temeljnih novinarskih postulata koji od njih zahtijevaju nepristranost, pozivanje na više izvora i zaštitu identiteta djece i mlađih maloljetnika. U završnom dijelu radu donosimo rezultate i analizu empirijskog istraživanja, a u zaključku ukazujemo na važnost stavljanja dobivenih rezultata u suodnos s novim istraživanjima, posebno onima koji bi bili usmjereni na objave na društvenim mrežama i na lažne vijesti koje se njima šire o izbjegličkoj i migrantskoj problematici.

Ključne riječi: izbjeglice, migranti, emigranti, mediji, hrvatske dnevne novine.

\footnotetext{
* Dr. sc. Suzana Peran, Hrvatsko katoličko sveučilište, Ilica 242, HR-10000 Zagreb.

** Anđelka Raguž, mag. nov., Hrvatski studiji Sveučilišta u Zagrebu, Borongajska cesta 83d, HR10000 Zagreb.
} 


\section{Uvod}

Val kretanja i prolaska izbjeglica i migranata ${ }^{1} \mathrm{kroz}$ Europu, ${ }^{2} \mathrm{koji}$ je (intenzivno) krenuo 2015. godine ${ }^{3}$ potaknuo je, među ostalim, propitivanje o (međunarodnim) političkim stavovima i zajedničkim odlukama usmjerenima prema (e) migrantima i izbjeglicama. Na razini Europske unije taj je val iznjedrio problem »nefunkcionalne i fragmentirane « politike Unije prema imigrantima, ${ }^{4}$ što je uvelike utjecalo i na sveopće stanje u Republici Hrvatskoj, ${ }^{5}$ posebno na oštru javnu raspravu sa stanovitim društvenim i političkim implikacijama te medijsku prezentaciju tih tema. Razjedinjenost stavova i javnih izjava izazvali su podijeljenost društva oko pitanja zaštite i pomoći izbjeglicama i migrantima koji svoje domove napuštaju (ili su ih napustili) zbog rata, sukoba, prijetnji, nasilja, političkih progona i gospodarske situacije u državama iz kojih dolaze ${ }^{6}$ ili zbog diskriminacije na temelju rase, etničke ili religijske pripadnosti, odnosno pripadanja određenoj društvenoj skupini. ${ }^{7}$ Izbjeglice i migranti svake godine u velikom broju dolaze na prostor Europske unije radi trajnog ostanka na području starog kontinenta. U skladu s time brojne su europske države bile primorane postavljati »interna pravila i smjernice « u vezi s intenzivnim priljevom ljudi i humanitarnom krizom koja je uslijed toga nastala.

Stoga je izuzetno važno promatrati i definirati ulogu i odgovornost medija u procesu prikazivanja izbjeglica jer je razvidno da mediji imaju središnju ulogu

\footnotetext{
${ }^{1}$ Najveći broj ljudi koji se određuju kao izbjeglice, migranti, tražitelji azila i/ili raseljene osobe u posljednjem valu njihova kretanja, dolaze iz Afganistana, Iraka, Pakistana i Sirije.

UNHCR, UNCHR Viewpoint. »Refugee « or »Migrant" " - Which is Right? (11.07.2016), http: // www.unhcr.org/news/latest/2016/7/55df0e556/unhcr-viewpoint-refugee-migrant-right.html (08.12.2018).

2 Prema podacima UNHCR-a izbjeglice čini: 40 \% djece, 38 \% muškaraca i 22 \% žena. Više u: UNCHR Viewpoint. »Refugee" or »Migrant" " - Which is Right?

${ }^{3}$ Dan 16. rujna 2015. se smatra prekretnicom u migracijskim tokovima u Europi, a potaknut je objavom fotografije mrtvog sirijskog dječaka Aylana Kurdija

${ }^{4}$ Usp. Ian TRAYNOR, Refugee crisis. Juncker calls for radical overhaul of EU immigration policies (09.09.2015), https://www.theguardian.com/world/2015/sep/09/refugee-crisis-euexecutive-plans-overhaul-of-european-asylum-policies (08.12.2018).

${ }^{5}$ Zapadno-balkanska ruta (Makedonija - Srbija - Mađarska - Hrvatska - Slovenija) uključuje prolazak migranata i izbjeglica i kroz prostor Republike Hrvatske; Senada ŠELO ŠABIĆ, Sonja BORIĆ, At The Gate of Europe. A Report on Refugees on the Westren Balkan Route; http:// www.irmo.hr/wp-content/uploads/2016/05/At -the-Gate-of-Europe_WEB.pdf (22.10.2018), a prema podacima Ministarstva unutarnjih poslova od rujna 2015. do ožujka 2016. godine u Hrvatsku je ušlo 658.068 migranata, od toga 558.724 u 2015. godini; http://stari.mup.hr/ main.aspx?id=188055 (08.12.2018). Gotovo svi su Hrvatsku napustili i dalje nastavili put prema zapadnoj Europi, dok je azil zatražilo 39 izbjeglica.

${ }^{6}$ Usp. Pinar YAZGAN, Deniz Eroglu UTKU, Ibrahim SIRECKI, Syrian Crisis and Migration, Migration Letters, 12 (2015) 3, 181-192, 180-182.

7 Usp. CENTAR ZA MIROVNE STUDIJE, Alternative detenciji za smještaj migranata koji u RH borave u iregularnom statusu (04.2016), https://www.asylumineurope.org/sites/default/files/ resources/alternative_detenciji_cms_inicijativa_dobrodosli.pdf (08.12.2018).
} 
pri informiranju javnosti o migracijama i statusu izbjeglica. ${ }^{8}$ Tako mediji s jedne strane predstavljaju ogledalo društva, a s druge istodobno utječu i na društvena i politička strujanja. 9 Slika izbjeglica u medijskom diskursu uvelike je oslonjena na »etiketu« stranaca i ilegalnih akcija, ${ }^{10}$ pri čemu oni imaju smanjenu mogućnost medijskih istupa u svoje ime. Izvještavajući o migrantima kao ilegalnim useljenicima i usredotočujući se u objavama na negativnosti vezane uz migrante, mediji - koji imaju ulogu pri oblikovanju javnog mnijenja i utjecaj na političke odluke svih razina - stvaraju polarizaciju u društvu. ${ }^{11} \mathrm{~S}$ time u vezi glavni je cilj ovoga empirijskog istraživanja, kvantitativnom analizom sadržaja objavljenog u trima najtiražnijim i najčitanijim hrvatskim dnevnim novinama: Jutarnjem listu, Večernjem listu i 24sata utvrditi frekventnost i način medijskog izvještavanja o »izbjegličkom valu« i prolasku izbjeglica i migranata preko teritorija Republike Hrvatske u periodu od 16. rujna 2015. do 1. travnja 2017. godine te pritom utvrditi usklađenost i/ili prijepore pri izvještavanju o temi našeg istraživanja. ${ }^{12}$ Unutar glavnog cilja osobito ćemo se usmjeriti na utvrđivanje stupnja pozitivnog i negativnog prikazivanja (stereotipnog uokvirivanja) slike izbjeglica te narav medijskog prikazivanja (informiranje, analiza, kritika, senzacionalistički pristup i kršenje etičkih normi i prava na privatnost djece i dostojanstvo) izbjeglica, azilanata i (e)migranata.

\section{Odnos i značenje pojmova: izbjeglice, migranti, emigranti $i$ azilanti}

Pri medijskom izvještavanju o prolasku izbjeglica i migranata, pojavljuju se i ponavljaju pojmovi koje smatramo da treba sadržajno odrediti da bi se što jasnije mogli donositi zaključci, jer je analiza sadržaja pokazala da medijski djelatnici istim pojmovima daju različita značenja, ovisno o načinu pristupa sadržaju, izboru riječi, stilu pisanja, uokviravanju teme i odabiru analitičkog ili »površnog« pristupa. S time u vezi valja se pojmovno ograničiti i stoga da bi se cilj i hipoteze empirijskog istraživanja mogli jasnije istražiti, potvrditi ili opovrgnuti, a ponajviše i stoga što se pojmovi izbjeglice, migranti, ekonomski migranti i tražitelji azila djelomično isprepliću.

${ }^{8}$ Usp. UNESCO, Media and migration, covering refugees crisis, https://en.unesco.org/news/ media-and-migration-covering-refugee-crisis (08.12.2018).

9 Usp. Mirko Juraj MATAUŠIĆ, Mediji u krizi vrednota, Bogoslovska smotra, 71 (2002) 2-3, 361 379.

${ }^{10}$ Usp. Terence WRIGHT, Moving Images. The Media Representation of Refugees, Visual Studies, 17 (2002) 1, 53-66, 64-65.

${ }^{11}$ Usp. Gualtiero ZAMBONINI, The Evolution of German Media Coverage of Migration, Washington, Migration Policy Institute, 2009, 2.

${ }^{12}$ Prema Agenciji za zaštitu tržišnog natjecanja najveću prodanu nakladu u 2016. godini, kao i u prethodne četiri godine, ostvario je list 24sata slijedi ga Jutarnji list, dok je treći po prodajnoj nakladi Večernji list, (20.04.2017) http://www.aztn.hr/8041/ (08.12.2018). 
Pojam izbjeglice ${ }^{13}$ trpi mnoge sociološke i jezikoslovne konstrukcije koje se zatim pojavljuju u većini medijskih objava. Taj se pojam poistovjećuje s ljudima »koji odlaze iz neke države svojom odlukom zato što im je život, na neki način, ugrožen ${ }^{14}{ }^{14}$ a takvo se poimanje nastavlja na sljedeću skupinu pojmova: migrirati, migranti, imigranti te emigranti. Migrirati - podrazumijeva "promijeniti/ mijenjati mjesto stalnog boravka, konačno ili privremeno.« Slijedom toga migrant je onaj koji mijenja mjesto boravka privremeno ili konačno ${ }^{15}$ najčešće zbog ekonomski narušenih uvjeta za život i rad, no migranti su, za razliku od izbjeglica, u mogućnosti vratiti se u svoju državu ${ }_{1}^{16}$ a do tada »zakonitim ili nezakonitim putovima tražiti posao u drugoj zemlii«. ${ }^{17}$

Emigrirati ima isti korijen riječi, no bitno drugačije značenje: »iseliti/iseljavati prisilno ili dobrovoljno iz domovine u tuđinu na određeno vrijeme ili trajno iz ekonomskih ili političkih razloga«. Stoga je emigrant »osoba koja je zbog određenih [objektivnih] ${ }^{18}$ razloga, morala napustiti zemlju «. ${ }^{19}$

Izbjeglica u širem smislu podrazumijeva »osobu u bijegu od rata ili, primjerice, prirodne katastrofe, ali ujedno može biti i tražitelj azila s uspješnim zahtjevom u skladu s Konvencijom o statusu izbjeglica iz 1951. godine na temelju prije navedenih strahova. Osoba može biti tražitelj azila onoliko dugo koliko traje njegova prijava i/ili možebitna žalba protiv odbijanja zahtjeva«. Azil je i »pravo političkog bjegunca na utočište u nekoj stranoj državi (uključujući zgradu stranog diplomatskog predstavništva) «. ${ }^{20}$

Premda preporuke i smjernice medijskim djelatnicima o tome na koji način trebaju izvještavati o manjinama, slabijima članovima društva i različitostima, postoje i jasno su artikulirane, ponajprije u novinarskoj praksi i obrazovnim

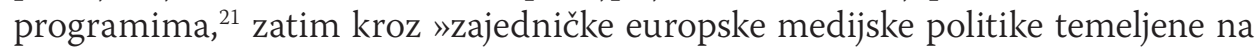
Europskoj konvenciji za zaštitu ljudskih prava i temeljnih sloboda«, ${ }^{22}$ još se uvijek

\footnotetext{
${ }^{13}$ Riječ je o osobi »koja se boji progona zbog svoje rase, vjere, nacionalnosti, pripadnosti nekoj društvenoj skupini i/ili političkih uvjerenja te se zbog toga nađe izvan zemlje čije državljanstvo posjeduje i koja ima strah prema životu u toj zemlji; te osoba, koja ako ne posjeduje državljanstvo, a nalazi se izvan države u kojoj je imala boravište, ali se zbog straha i zbog takvih događaja u tu državu ne želi vratiti« (UN, Konvencije o statusu izbjeglica, 2008, čl. 2).

${ }^{14}$ Zrinka JELASKA, Vrste nasljednih govornika, Lahor - časopis za hrvatski kao materinski, drugi i strani jezik, 1 (2014) 17, 83-105, 98-99.

${ }^{15}$ Usp. "Migrirati«, Hrvatski jezični portal, http://hjp.znanje.hr/index.php?show=search (08.12.2018).

${ }^{16}$ Usp. UNHCR, UNHCR Statistical Yearbook 2014, http://www.unhcr.org/56655f4d8.html (08.12.2018).

${ }^{17}$ Harry MITCHELL, The Distinction Between Asylum Seekers and Refugees, (01.08.2017) http:// www.migrationwatchuk.org/briefing-paper/70 (08.12.2018).

${ }^{18}$ Sadržaj u uglatoj zagradi dodale autorice rada.

${ }_{19}$ »Emigrant«, Hrvatski jezični portal, http://hjp.znanje.hr/index.php?show=search (08.12.2018).

${ }^{20}{ }$ Azil«, Hrvatski jezični portal, http://hjp.znanje.hr/index.php?show=search (08.12.2018).

${ }^{21}$ Usp. Thomas BAUER i dr., Priručnik za predavače novinarstva, Zagreb, JETiC, 2007.

${ }^{22}$ Irina MILUTINOVIĆ, Protivrečnosti evropske medijske politike, Communication and Media, 42 (2018) 13, 105-132.
} 
u suvremenim medijskim objavama, nalaze i propušteni prijepori kroz konotacije, senzacionalizam i govor mržnje. ${ }^{23}$

Od srpnja 2015. godine europski su mediji (posljedično i hrvatski) označavali ljude koji su dolazili brodovima na europsko tlo kao migrante, premda je po pojmovnom određenju to neutralna riječ - ljudi koji se sele iz jedne države u drugu. U to je vrijeme došao i eksplicitni poticaj UN-ove agencije za izbjeglice te od medijskih kuća, poput Al Jazeere, da se koriste manje pejorativni izrazi za opis tih ljudi u kretanju. Kao alternativna mogućnost preporučena je riječ izbjeglica.

»Preko noći migrantska se kriza tako u medijskim krugovima promijenila u izbjegličku krizu, a svatko tko je preispitivao promjenu bio je promatran kao netko tko ne suosjeća s neprilikama njezinih protagonista. ${ }^{24}$

Povrh toga, osim distinkcije izbjeglica - migrant, u odabiru riječi kojima su se koristili mediji te akteri čije su izjave mediji prenosili, mogli su se uočiti dehumanizirajući opisi izbjeglica. To se ponajprije odnosi na korištenje izraza kojima se češće opisuju prirodne pojave i ponašanje životinja. U hrvatskom se medijskom diskursu često koristio izraz izbjeglički ili migrantski val. Isti se izraz koristio i na engleskom govornome području (wave) kao i - priljev i dotok. Navedeni se izrazi koriste za opis prirodnih procesa u vezi s vodom, a označavaju pojave koje je vrlo teško kontrolirati. Uz navedene mogli su se, doduše manje i uz veću kritiku, plasirati i izrazi kojima se inače opisuje ponašanje kukaca, primjerice - najezda. ${ }^{25}$ Korištenje termina izbjeglice, migranti i emigranti u medijskim objavama mogla bi biti tema i nekog budućega istraživanja.

\section{Uloga medija pri izvještavanju o izbjeglicama i (e)migrantima}

Uloga je medija pri izvještavanju o kretanjima i statusu izbjeglica i migranata značajnija nego inače zbog brzine kojom su se događaji odvijali u drugoj polovici 2015. godine te s obzirom na značenje virtualnih ekstenzija i društvenih medija koji su služili kao platforma za širenje informacija i mnoštva lažnih informacija i netočnih vijesti. ${ }^{26}$ Nedostatne informacije koje su prikazivale kontekst i razloge dolazaka i prolazaka migranata kroz Hrvatsku, stvarale su o njima predrasude. ${ }^{27}$ Ta je brzina utjecala s jedne strane i na oblikovanje sintagme »izbjeglička kriza« u kontekstu tada aktualnih migracija, a s druge strane i na javno mnijenje i

\footnotetext{
${ }^{23}$ Usp. Gordana VILOVIĆ, Etički prijepori u Globusu i Nacionalu 1999.-2000., Zagreb, Fakultet političkih znanosti, 2004.

${ }^{24}$ Patrick KINGSLEY, Nova odiseja, Zagreb, Profil knjiga, 2016, 250.

${ }^{25}$ Usp. Sara LALIĆ, Uloga medija u oblikovanju javnog mnijenja prema izbjeglicama $i$ tzv. izbjegličkoj krizi, http://www.dostajemrznje.org/wp-content/uploads/2016/10/Uloga-medijau-oblikovanju-javnog-mnijenja-prema-izbjeglicama.pdf (08.12.2018), 5 .

${ }^{26}$ Usp. Myria GEORGIOU, Rafael ZABAROWSKI, Media coverage of the »refugee crisis «. A cross-European perspective, https://rm.coe.int/16806d8c9e (08.12.2018), 3.

${ }^{27}$ Usp. Lalić, Uloga medija u oblikovanju javnog mnijenja..., 4.
} 
tvorce političkih odluka, koji kreiraju događaje na terenu, te na njihovu ovisnost o medijski posredovanim podacima. Nedostatak valjanih (javnih) informacija o dolascima migranata, njihovoj povijesti i razlozima njihova stanja posljedično je utjecao i na negativniju sliku migranata u očima brojnih građana. Autori, dalje ističu, da je potreba za analizom medijske pokrivenosti izbjegličke migracijske krize, ključna i za razumijevanje - »pripovijesti o krizi, zemljopisnih trendova te političkih izazova za donošenje novih politika, osobito u vezi s govorom mržnje i slobodom izražavanja«. ${ }^{28}$

U izvještaju Mreže etičkog novinarstva iz 2015. godine ${ }^{29}$ navodi se da mediji u Europskoj uniji ne uspijevaju pružiti ravnotežu u izvještavanju, a na odluke političkih vodstava odgovaraju panikom i najavljuju dizanje zidova i bodljikavih žica uzduž granica. Jednako tako, postupanje s migrantima uključuje osjećaje nesigurnosti i nelagode što mediji mogu iskoristiti da bi »umjetno« stvorili stanje u kojem se migranti prikazuju kao »neprijatelji na vratima«. Takvi prikazi i stvaranje slika mogu dovesti do dehumanizacije, koja »uključuje odbijanje pune ljudskosti od strane drugih te njihovo isključivanje iz ljudske vrste ${ }^{30} \mathrm{~S}$ time u vezi autori navode da su u posljednjem desetljeću medijski izvještaji o migrantima u zapadnim zemljama postali vrlo negativni, ${ }^{31}$ a mediji se fokusiraju na moguće prijetnje koje izbjeglice predstavljaju za državljane nekih zemalja.

\section{Metoda istraživanja i dizajn istraživačke analize}

Empirijsko je istraživanje za potrebe ovoga članka provedeno metodom kvantitativne analize sadržaja - najčešće korištene metode prilikom promatranja zastupljenosti određenih tema ili problema u medijima, oslonjene na objektivnost, ${ }^{32}$ sustavnost ${ }^{33}$ i općenitost. ${ }^{34}$ Kvantitativna istraživanja, statističkim obradama i

\footnotetext{
${ }^{28}$ Georgiou, Zabarowski, Media coverage of the »refugee crisis«..., 10.

${ }^{29}$ Migration. Global Report on Journalism's Biggest Test in 2015; http://ethicaljournalismnetwork. org/press-release-migration-global-report-on-journalism-s-biggest-test-in-2015 (08.11.2018).

${ }^{30}$ Victoria MESSES, Stelian MEDIANU, Andrea SLAWSON, Uncertainty, threat, and the role of the media in promoting the dehumanization of immigrants and refugees (09.09.2013), http:// onlinelibrary.wiley.com/doi/10.1111/josi.12027/full\#publication-history (08.12.2018).

${ }^{31}$ Njemački su mediji u izvještavanju o imigrantima koristili sintagmu »brod je pun « (Zambonini, The Evolution of German Media Coverage of Migration..., 3).

32 »Nezavisnost rezultata istraživanja od istraživača koji ih je dobio, a postiže se slijeđenjem jasnih i propisanih pravila« (Goran MILAS, Istraživačke metode u psihologiji i drugim društvenim znanostima, Jastrebarsko, Naklada Slap, 2009, 501).

33 »Pravila prema kojima se izvaci materijala uključuju ili isključuju iz analize pri čemu istraživač ne smije dokazivati vlastite pretpostavke nego se mora držati unaprijed utvrđenih načela" (isto); teorijsko značenje koji bi trebalo nadići opisivanje sadržaja, a pokazuje znanstvenu vrijednost analize sadržaja (isto).

${ }^{34}$ Teorijsko značenje koji bi trebalo nadići opisivanje sadržaja, a pokazuje znanstvenu vrijednost analize sadržaja (isto, 501).
} 
sažimanjem izvornih podataka omogućuje brojčani opis istraživane pojave, ${ }^{35}$ a određuju ih »tehnike kojima se na objektivan i sustavan način kvantitativno opisuje sadržaj nekog aspekta komunikacije «, ${ }^{36}$ a prije provedbe samog istraživanja radi se uzorkovanje, određivanje jedinice analize i jedinice sadržaja kategorija, kodiranje i naposljetku statistička analiza. ${ }^{37}$

Analiza sadržaja korisna je istraživačka metoda i kada opsežnost ili brojnost materijala ne dopušta cjelovitu analizu na svoj dostupnoj građi, »već osobine tekstualnog i/ili vizualnog materijala ukazuju na ukupni dio promatranih osobina u uzorku izabranom iz određene populacije «, ${ }^{38}$ a istodobno se njezinom namjenom žele opisati obilježja komunikacije, zaključivati o događajima koji su joj prethodili kao i o njezinim učincima, odgovarajući na tri ključna pitanja: što komunikacija donosi, kako to čini i kome se obraća? ${ }^{39}$ Sukladno tome ta istraživačka metoda omogućuje i stvaranje zaključaka na temelju sustavnih i objektivnih značajki objavljene medijske poruke. ${ }^{40}$

Prema tomu, kako bi se utvrdilo - frekventnost, pravilnost i usklađenost novinarskog izvještavanja, stupanj pozitivnog i negativnog prikazivanja analizirane ciljane skupine, priroda novinarskog prikaza teme istraživanja - analiza sadržaja pogodna je metoda i jer se izravnim putem kvantificiraju unaprijed zadane istraživačke varijable. Nadalje ta metoda omogućuje i analiziranje velikog broja tekstova i uspoređivanje sadržaja na temelju razlika unutar teksta te je i stoga pogodna za naše istraživanje, jer omogućuje usporedbu medijskog izvještavanja u nacionalnim dnevnim novinama o izbjegličkom valu i prolasku izbjeglica preko teritorija Republike Hrvatske kroz longitudinalni okvir.

\subsection{Uzorkovanje i vremenski raspon}

Analizom su obuhvaćene novinske objave u trima najtiražnijim i najčitanijim hrvatskim dnevnim novinama od 16. rujna 2015. do 1. travnja 2017. godine. Analiza je uključila novinske objave tiskanih izdanja Jutarnjeg lista, Večernjeg lista i 24sata, a uzorak čini ukupno 164 novinskih objava u 59 izdanja dnevnih novina u šestomjesečnom razdoblju. U tome razdoblju o izbjeglicama je najviše izvještavao Večernji list (72), zatim Jutarnji list sa 69 objavljena teksta i, napo-

\footnotetext{
${ }^{35}$ Usp. isto, 47.

${ }^{36}$ Isto, 500.

${ }^{37}$ Usp. isto, 506.

${ }^{38}$ Vesna LAMZA POSAVEC, Metode istraživanja u novinarstvu, Zagreb, Fakultet političkih znanosti Sveučilišta u Zagrebu, 2006, 152.

${ }^{39}$ Usp. Ole R. HOLSTI, Content Analysis for the Social Science and Humanities, Reading, Adisson-Wesley, 1969, 599.

${ }^{40}$ Usp. Blanka JERGOVIĆ, Anđelka RAGUŽ, Koliko je znanost važna tema u hrvatskim dnevnim novinama? Analiza napisa objavljenih 2012. godine u Jutarnjem listu, Večernjem listu, Slobodnoj Dalmaciji i Novom listu, Medijske studije, 5 (2014) 10, 36-50, 39 prema: Holsti, Content Analysis..., 14.
} 
sljetku, najrjeđe 24sata (23). O toj su temi najtiražnije hrvatske dnevne novine, najviše izvještavale tijekom rujna 2015. godine (ukupno je objavljeno 63 priloga), dok se tijekom travnja, lipnja i prosinca u 2016. godini uopće nije izvještavalo o izbjeglicama.

Jedinicu analize činila je novinska objava čija je tema: izbjeglice, (e)migranti i azilanti. Uzorak je ograničen na tri dana svakog mjeseca, a dani su odabrani metodom slučajnih brojeva što je omogućilo kontinuitet, jer nije riječ o posebnim prilozima i/ili rubrikama posvećenima isključivo odabranoj temi u hrvatskim dnevnim novinama. Uzorkovanje je izvršeno tako da su odabrani i zatim analizirani one novinske objave čiji je sadržaj tematski posvećen izbjegličkom valu i prolasku izbjeglica i (e)migranata kroz teritorij Republike Hrvatske. Premda je uzorak izabran prema unaprijed utvrđenim i definiranim kriterijima istraživača, on pripada grupi probabilističkih uzoraka, a prema vrsti je slučajni sustavni jer odabirom ove vrste sve jedinice osnovnog skupa imaju jednake izglede da budu dijelom uzorka. S obzirom na razdoblje, istraživanje je transverzalno jer proučava pojavu u određenom vremenskom trenutku. Stoga rezultati takvog istraživanja omogućuju uvid u karakteristike proučavane pojave ili procesa u trenutku provođenja istraživanja. ${ }^{41}$

Za potrebe istraživanja izrađena je analitička matrica koja je sadržavala 26 klasificiranih kategorija, podijeljenih u pet cjelina (opća pitanja koja bilježe kojoj analiziranoj novini novinska objava pripada te kada je objavljena, drugi dio obuhvaća žanrovske karakteristike objave, dok se treći dio odnosi na autorstvo, broj i vrstu izvora koji se u objavi pojavljuju; u četvrtom dijelu analizirani su naslovi novinske objave i oprema, a posljednja cjelina analize usmjerena je na stupanj pozitivnog, odnosno negativnog prikazivanja ciljane skupine te prirodu novinarskog prikaza teme istraživanja).

\subsection{Ciljevi i hipoteze istraživanja}

Generalni je cilj istraživanja bio utvrđivanje frekventnosti i načina medijskog izvještavanja o izbjegličkom valu i prolasku izbjeglica i migranata preko teritorija Republike Hrvatske u periodu od 16. rujna 2015. do 1. travnja 2017. godine te usklađenosti i/ili prijepora pri izvještavanju o predmetu istraživanja. Specifični su ciljevi istraživanja bili utvrđivanje stupnja pozitivnog i/ili negativnog prikazivanja izbjeglica te naravi medijskog prikazivanja (informiranje, analiza, kritika, senzacionalistički pristup i kršenje etičkih normi i prava na privatnost djece i dostojanstvo) izbjeglica, azilanata i (e)migranata.

U okviru istraživanja postavljene su četiri hipoteze koje će rezultatima istraživanja biti potvrđene ili opovrgnute:

\footnotetext{
${ }^{41}$ Usp. Milas, Istraživačke metode..., 507.
} 
1. Medijsko izvještavanje o izbjeglicama u većem broju slučajeva uključuje senzacionalistički pristup temi.

2. Izbjeglice se prikazuje kao prijetnju gospodarskoj stabilnosti Republike Hrvatske.

3. Novinski prilozi apeliraju na emocije čitatelja.

4. Izbjeglice se predstavlja kao potencijalnu terorističku prijetnju.

\section{Analiza i interpretacija rezultata}

\subsection{Rubrike i teme priloga o izbjeglicama u dnevnim novinama}

»Smještajući priloge u rubrike, novinari i urednici odabiru temu, a odabirom tipa i veličine novinskog članka utječu na istaknutost pojedine vijesti.« «2 Analiza sadržaja tako pokazuje da se gotovo 90 \% objava o izbjeglicama i (e)migrantima pojavljivalo u rubrikama koje su se odnosile na aktualnosti i novosti (Jutarnji list $-87 \%$, Večernji list $-88,9 \%$, 24sata $-95,7 \%$ ). Te rezultate povezujemo s tim da je većina tekstova bila informativne vrste te su samo informirali javnost o pojedinim novostima u vezi s prolaskom i eventualnim zadržavanjem izbjeglica na području Republike Hrvatske. Detaljnije i sustavne analiza bile su rijetke, a u malom broju slučajeva hrvatske dnevne novine tu su temu obrađivale kroz komentatorske retke (Jutarnji list - 5,8 \%, Večernji list - 6,9 \% i 24sata - 4,3\%). Svega $2 \%$ svih objavljenih tekstova nalazilo se na stranicama rubrike Unutarnja politika, što je samo po sebi kontradiktorno jer su pitanja prolaska i smještaja izbjeglica preko hrvatskog teritorija bila itekako značajna za područje unutarnje politike. Većina su objava kratki tekstovi (35\%), odnosno objave duljine do pola novinske stranice. Zatim slijede vijesti i kratke vijesti (26\%), a u petini od ukupnog broja objava bilo je riječi o analizi, koju je, za razliku od ostale dvije analizirane dnevne novine, u najviše slučajeva $(30,4$ \%) objavio dnevnik 24 sata. Kvantitativno je u analiziranim dnevnim novinama najmanje objavljeno komentara $(6,5 \%)$ i ostalih novinskih vrsta $(1,4 \%)$.

Prema podacima iz grafikona sa slike broj 1 razvidno je da su analizom obuhvaćene objave većinom informativno-izvještajne vrste, njih ukupno 82,4 \%, a 16,6 \% članaka su reportažno-komentatorske vrste. Iz toga se može zaključiti da je cilj medijskih djelatnika bio ponajprije informirati širu publiku o odabranim činjenicama i podacima u vezi s izbjeglicama. Sadržaj znatno manjeg broja objava je pokušavao izazvati »estetski doživljaj« kod čitatelja i uključivao djelomične analize o tim temama. Stoga je jasno da je prva naša hipoteza odbačena jer medijski djelatnici teme o prolasku izbjeglica preko teritorija Republike Hrvatske nisu oblikovali senzacionalističkim pristupom.

\footnotetext{
${ }^{42}$ Jergović, Raguž, Koliko je znanost važna tema..., 41.
} 


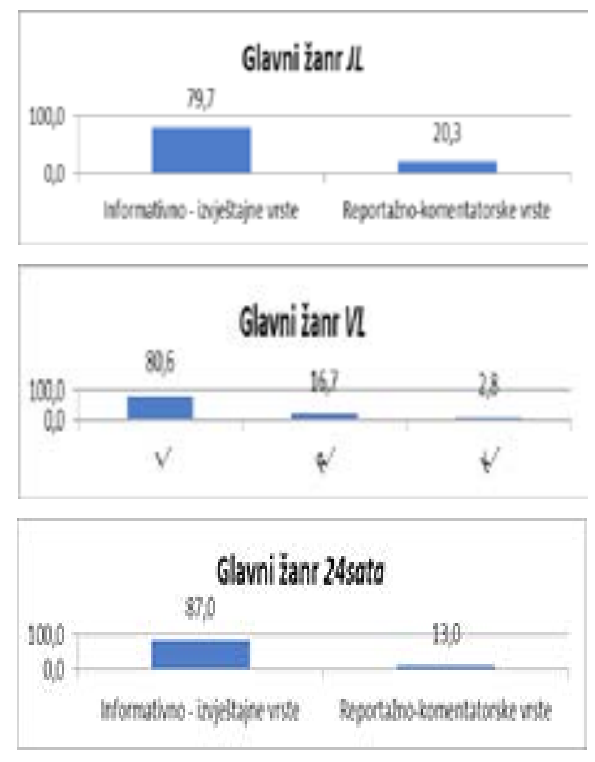

Slika 1. Glavni žanrovi N $(\%)=164$

U vrijeme intenzivnog prolaska izbjeglica i migranata preko teritorija Republike Hrvatske, nacionalne su dnevne novine objavile svega četiri teksta (samo Večernji list), odnosno u 5,6 \% slučajeva, osobne ispovijesti izbjeglica i na taj im način pružili prostor u kojem mogu predstaviti razloge dolaska, svoje potrebe i/ ili teške životne situacije s kojima su suočeni. U petini objavljenog sadržaja Jutarnjeg lista i Večernjeg lista prevladavaju teme u vezi s kontrolom izbjeglica i nadziranje njihovih ulazaka te stanjima na graničnim prijelazima (tablica 1). Ulazak izbjeglica u državu tema je koja prevladava u analiziranom uzorku objava 24sata. Ova se tema nalazi u 11 od ukupna 23 objava, odnosno u 47,8 \% slučajeva. U istom se omjeru (13\%) pojavljuju i teme kontrole izbjeglica/nadziranja granica te izbjegličkih kampova. Situacije u kojima su građani pomagali izbjeglicama bile su teme $8,7 \%$ objava potonjih dnevnih novina i u svega $4,3 \%$ (Jutarnji list), odnosno, 2,8 \% (Večernji list) objava u preostalim analiziranim novinama, što nije u skladu s društvenom situacijom i polemikama koje su se vodile u javnosti neposredno prije dolaska imigranata, a i zbog činjenice da su u konačnici građani preuzeli dio odgovornosti oko zbrinjavanja i pomoći pristiglom ljudstvu.

Tablica 1. Glavna tema članka N $(\%)=164$

\begin{tabular}{|l|c|c|c|}
\hline \multicolumn{1}{|c|}{ TEMA } & $\begin{array}{c}\text { Jutarnji } \\
\text { list } \mathbf{( \% )}\end{array}$ & $\begin{array}{c}\text { Večernji } \\
\text { list } \mathbf{( \% )}\end{array}$ & $\begin{array}{c}\text { 24sata } \\
(\%)\end{array}$ \\
\hline Ulazak izbjeglica u RH & 11,6 & 12,5 & $\mathbf{4 7 , 8}$ \\
\hline Ilegalni ulasci u državu & 0 & 1,4 & 0 \\
\hline Zdravstveno stanje & 0 & 2,8 & 0 \\
\hline
\end{tabular}




\begin{tabular}{|l|c|c|c|}
\hline Statistički podatci/pregled situacije & 14,5 & 5,6 & 4,3 \\
\hline Suradnja država & 14,5 & 16,7 & 0 \\
\hline Trivijalni sadržaj & 1,4 & 4,2 & 4,3 \\
\hline Građani pomažu izbjeglicama & 4,3 & 2,8 & 8,7 \\
\hline Ispovijest izbjeglica (životna priča jedne ili više osoba) & 1,4 & 4,2 & 0 \\
\hline Izbjeglice napuštaju zemlju & 4,3 & 1,4 & 0 \\
\hline Dizanje ograde na granici & 11,6 & 5,6 & 4,3 \\
\hline Kontrola izbjeglica/nadziranje granica & $\mathbf{2 0 , 3}$ & $\mathbf{2 2 , 2}$ & 13,0 \\
\hline Izbjeglički kampovi & 2,9 & 5,6 & 13,0 \\
\hline Napad na izbjeglice (fizički ili verbalni) & 2,9 & 0 & 0 \\
\hline Ostalo & 10,1 & 15,3 & 4,3 \\
\hline Ukupno & 100 & 100 & 100 \\
\hline
\end{tabular}

\subsection{Primarni fokus priloga $i$ ton tekstualne i vizualne komunikacije}

S obzirom na cilj, svrhu i hipoteze istraživanja, nužno je bilo analizirani sadržaj međusobno usporediti s jedne strane, a s druge istodobno uočiti jesu li istim sadržajima medijski djelatnici različito pristupali da bi se među ostalim ustanovilo kolik i kakav je »medijski tretman« dan izbjeglicama koji su tijekom 2015. godine prolazili Hrvatskom na putu prema zemljama zapadne Europe. Sa stajalište teorije o izravnim medijskim učincima jasno je da je odnos medija, medijskih djelatnika, uredništva i nakladnika prema nekoj temi značajan pokazatelj ponajprije (uredničkih) stavova prema društvenom problemu. Važno je pri tome podsjetiti da upravo uređivačka (nakladnička) politika može u konačnici utjecati na stavove publike te time neizravno i na participaciju u demokratskim procesima i pritom »vrlo snažno djelovati na svijest ljudi, posebno na duže razdoblje«. ${ }^{43}$ Prilikom razmatranja prostora koji je dan konkretnom predmetu istraživanja, $\mathrm{u}$ obzir treba uzeti i ulogu jezika, izbor riječi i sintagmi te novinarev stil pisanja i odabir vizualne prezentacije izbjeglica i migranata. Zbog toga, ono može biti povezano i s »medijskom mogućnosti« utjecanja i na krajnje oblikovanje puta prema kreiranju stava, koje je, uz objektivnost, još uvijek »iluzija kojom se lako može manipulirati, ovisno o potrebi izvještavanja«. ${ }^{44}$

Ukupni rezultati istraživanja, s time u vezi, pokazuju da su u većini objavljenih priloga u dnevnim novinama, migranti i izbjeglice prikazani na dva (različita) načina. Naime, tekstualni prikaz ne prati vizualnu prezentaciju. Konkretno odabrane su fotografije u suprotnosti s napisanim. Analiza je pokazala da je (Jutarnji list - 73,9\%, Večernji list - 65,2 \% i 24sata - 43,5\%) tekstualni prikaz izbjeglica uglavnom bio neutralan. Četvrtina ukupnih objava (Večernji list prednjači s 15 članaka) izbjeglice je prikazala »etiketirano«. Premda smo u istraživačkoj matri-

\footnotetext{
${ }^{43}$ Suzana PERAN, Slika obitelji u hrvatskim medijima - mediji i katolički nauk o obitelji, Doktorski rad, Zagreb, Sveučilište u Zagrebu, 2012, 2.

${ }^{44}$ Robert JENSEN, Fighting Objectivity. The Illusion of Journalistic Neutrality in Coverage of the Persian Gulf War, Journal of Communication Inquiry, 16 (1992) 1, 20-32, 21.
} 
ci (kreiranoj u fazi konceptualizacije istraživanja) ponudili mogućnost prikaza objekata istraživanja kao prijetnje gospodarskoj stabilnosti države, povezivanje s nasiljem, radikalnim islamom i terorističkim skupinama, odnosno napadima, analiza objavljenog sadržaja je pokazala da su u svega jednom članku iz Jutarnjeg lista i jednom iz 24sata te u 7 \% Večernjakovog sadržaja, izbjeglice i migranti prikazani kao prijetnje hrvatskoj ekonomskoj stabilnosti te u 4,2 \% sadržaja iz potonje dnevne novine pojavljuje se izjednačavanje izbjeglica s teroristima. $\mathrm{Na}$ temelju toga, druga (izbjeglice se prikazuje kao prijetnju gospodarskoj stabilnosti Republike Hrvatske)i četvrta hipoteza (izbjeglice se predstavlja kao potencijalnu terorističku prijetnju) nisu potvrđene.

Stoga je izuzetno značajan i zabrinjavajuć podatak da su povreda (ljudskog) dostojanstva izbjeglica, diskriminirajući opisi, omalovažavanje i prikazivanje izbjeglica kao manje vrijednih ljudi zabilježene u čak 8,7 \% objava 24 sata, odnosno u jednom tekstu iz Večernjeg lista, prikazuje ih se manje vrijednima. Ostale (iskrivljene) slike, usporedbe, pretpostavke i povezivanje s izbjeglicama u analizom obuhvaćenom sadržaju nisu prepoznate.

Premda je kvantitativno pet novinskih objava statistički malena vrijednost, ipak nam je važan podatak da je svojim tekstovima Večernji list metaforički ili asocijativno pozivao čitatelje na mržnju, strah ili gađenje prema izbjeglicama, dok su, s druge strane, medijski djelatnici jedinoga hrvatskog tabloida 24sata u 13 \% svojih objava metaforički i asocijativno pozivali na gađenje ili sram prema onim domicilnim građanima koji ne prihvaćaju izbjeglice. Članak iz Jutarnjeg lista od 29. rujna 2015., pod naslovom »Donirao sam bika za izbjeglice jer sam i sam jednom morao bježati od rata «, ${ }^{45}$ jedan je od rijetkih primjera iz analiziranih hrvatskih dnevnih novina kojima se apeliralo i ukazivalo na pomoć izbjeglicama. Navedeni podaci ukazuju ponajprije na to da $u$ analizom obuhvaćenom razdoblju objavljeni i analizirani novinski prilozi nisu u većem broju slučajeva izravno apelirali na emocije čitatelja, odnosno, gledano u cjelini, u gotovo $82 \%$ priloga, hrvatske dnevne novine nisu iskoristile mogućnost četvrte vlasti ${ }^{46} \mathrm{da}$ upute publiku na pomoć i suosjećanje s izbjeglicama, odnosno da daju izravnu sugestiju/apel čitateljima da pomognu izbjeglicama. Zaključno, navedeni empirijski rezultati nisu potvrdili treću hipotezu ${ }^{47}$ našega rada.

Nadalje, vizualne prezentacije izbjeglica i (e)migranata nisu pratile svaki analizirani tekstualni sadržaj. Fotografije je Jutarnji list objavio uz 43,5 \% članaka, u Večernjem listu 59,7 \% novinskih članaka nije imalo popratnu fotografiju (e) migranata i izbjeglica. Također, u 39 \% slučajeva oni se uopće ne prikazuju na fotografijama iz 24sata, ali su zato u $30 \%$ objavljenih prikaza u jednakom broju slike na kojima su migranti uplakani, ozlijeđeni i/ili u opasnoj situaciji i na kojima nisu tako prikazani. Vizualne opreme objava Jutarnjeg lista, u tri posto

\footnotetext{
${ }^{45}$ Riječ je o intervjuu novinara Zlatka Šimića s Ivom Serdarom.

${ }^{46}$ Više u: Mark HAMPTON, The fourth estate ideal in journalism history, u: Stuart ALLAN (ur.), The routledge companion to news and journalism, London, Routledge, 2010, 3-12.

${ }^{47}$ Novinski prilozi apeliraju na emocije čitatelja.
} 
zabilježenih slučajeva, povezivale su migrante i izbjeglice s nasilnim ponašanjem uz konstrukcije »opasnih ljudi«, dok su u trostruko više objava (9,7 \%) u Večernjem listu prikazani uplakani, ozlijeđeni ili kao sudionici opasnih situacija. Kada usporedimo rezultate analize fotografija unutar novinskih objava, značajne su razlike vidljive kod 24sata. U usporedbi s Večernjim listom i Jutarnjim listom, u 24sata češće se (43\%) apeliralo na suosjećanje i pomoć izbjeglicama kroz vizualne zapise, ali je istodobno u 34,8 \% objavljenih fotografija povrijeđeno ljudsko dostojanstvo prikazanih osoba.

Medijski prikaz djece (na fotografijama i tekstualno) uvijek je posebno osjetljivo područje i predmnijeva izuzetne napore i regulaciju da bi se osigurao ne samo senzibilitet medijskih djelatnika, već napose primjenjiva zakonska regulativa o pravu djece i mlađih maloljetnika na privatnost. Analiza je pokazala da su u više od $45 \%$ slučajeva djeca glavni akteri pri medijskom izvještavanju o prolasku izbjeglica kroz teritorij Hrvatske. Uslijed toga, u Jutarnjem listu u 23,3 \% slučajeva, na fotografiji ili u tekstu, otkriven je identitet djeteta (izravno ili neizravno), u 7,2 \% članaka identitet je zaštićen, dok 33,3 \% čine fotografije koje ih prikazuju. Primjećujemo da je postotak prikaza djece na fotografijama iz Večernjeg lista nešto veći nego u objavama Jutarnjeg lista. Identitet djece, u člancima u kojima se spominju, više je otkriven nego neotkriven. Naime, u 15 (20,8 \%) od ukupno 72 članka Večernjeg lista, izravno ili neizravno, može se saznati (razaznati) identitet djeteta. U dnevnim novinama 24sata pravo na privatnost djece prekršeno je na fotografiji ili u tekstu u čak 43,5\% slučajeva.

Načini na koje se pristupa(lo) mlađim maloljetnicima i djeci-izbjeglicama i posljedično eksplicitno otkrivanje njihova identiteta prikazani su kroz primjere u nastavku. U objavi Jutarnjeg lista od 26. srpnja 2016. godine, pod naslovom »Trojica Afganistanaca pobjegli su iz Splita«, u kojoj je istaknuto da su dječaci pobjegli sa splitske lokacije na kojoj su bili privremeno smješteni, prekršeno je pravo na privatnost zbog objave fotografija svih mladića (na jednoj su slici oči grafički zamućene), uza što su navedena i njihova točna imena te dob. Drugi primjer je iz 24sata, članak, čiji je naslov: »Nestalo šest izbjeglica«, objavljen 19. siječnja 2017., navodi da su tri maloljetnika pobjegla iz doma u Zagrebu, podsjećajući (i uspoređujući), također, kako dječaci koji su nestali u Splitu godinu dana prije još uvijek nisu pronađeni. Fotografije koje su priložene uz taj tekst identične su onima koje su bile objavljene u Jutarnjem listu godinu dana prije.

S obzirom na to da su fotografije izuzetno važan medij za prijenos vizualne informacije ${ }^{48}$ i uz naslov mogu snažno utjecati na čitateljevu svijest, ovakvi rezultati pokazuju da su uredništva hrvatskih dnevnih novina identitet djece na fotografijama otkrivali i u slučajevima siromaštva, bolesti i razdvajanja obitelji, da bi senzibilizirali javnost i potaknuli na akciju (pružanje pomoći), premda to samo po sebi može izazvati »etiketiranje« i porugu spram djece i obitelji. Takvo je izvještavanje potvrdilo i prijašnja saznanja o tome da hrvatski mediji prostor

\footnotetext{
${ }^{48}$ Usp. Stjepan MALOVIĆ, Osnove novinarstva, Zagreb, Golden marketing - Tehnička knjiga,
} 2005, 341. 
djeci daju najčešće u izvještaju o nasilju, nesrećama, zlostavljanjima, bolestima i/ ili nekom drugom neprimjerenom obliku ponašanja. ${ }^{49}$ Stoga je $u$ istraživanjima nužno potpuno eliminirati i empirijski promatrati priloge koji generaliziraju na temelju pojedinačnih slučajeva, te djecu prikazuju kao potencijalno opasne i agresivne članove društva i one koji su potencijalna prijetnja društvu. ${ }^{50}$

\subsection{Autorstvo teksta i izvori informacija}

Rezultati našega empirijskog istraživanja upućuju na to da je u većini objavljenih priloga riječ o autorskom radu novinara (Jutarnji list - 76,5\%, Večernji list - 97,2 \% i 24sata - 73,8 \%) s naglaskom na brojčanu zastupljenost potpisa autora punim imenom i prezimenom (Jutarnji list - 53 \%, Večernji list - 65,3 \% i 24sata $-39 \%$ ) te u nešto manjem broju slučajeva bili su redakcijski potpisi. Nešto manje od četvrtine objava iz Jutarnjeg lista (23,5 \%) i čak 39,1 \% iz 24sata bilo je nepotpisano, bez navođenja imena, inicijala ili redakcijskog potpisa. Distanciranost od sadržaja u ovom je slučaju značajna jer ukazuje na odmak medijskog djelatnika od onoga o čemu izvještava, a prema Benu Bagdikianu, novinar svojim radom ne može biti imun na ljude i događaje o kojima izvještava pa samim time implicitno utječe i na vlastitu pristranost, ${ }^{51}$ ostavljajući tako prostor ekstrinzičnim (primarno individualnim) razlozima, poput subjektivnih stavova i percepcije te nazora pretpostavljenih ili utjecaja nekih skupina..$^{52}$ Istodobno, dvije opće potrebe i funkcije koje uključuju psihološko-kognitivne procese mogu utjecati na spomenuti proces: potreba za očuvanjem vlastitih novinarovih predispozicija i želja za socijalnim potvrđivanjem osobnih percepcija. U usporedbi s time, sva tri analizirana dnevna lista većinom su informirali publiku samo o činjenicama jer su u 82,5\% objavljene samo informacije, a u 8,6 \% slučajeva, uz informacije, primjetni su i stavovi autora priloga.

Jutarnji list se u većini svojih objava oslanjao na isključivo jedan izvor (49,3 $\%$ ), bilo da je riječ o imenovanim ${ }^{53}$ ili neimenovanim ${ }^{54}$ izvorima, a u 30,4 \% čla-

\footnotetext{
${ }^{49}$ Usp. Mila JELAVIĆ, Djeca u medijima: kako im osigurati pravo na privatnost?, u: Maja FLEGO (ur.), Zaštita privatnosti djece u medijima, Zagreb, Pravobranitelj za djecu, 2009, 7-19, 14.

${ }^{50}$ Usp. Danijel LABAŠ, Leali OSMANČEVIĆ, Dječji domovi u hrvatskom tisku u 2012. godini. Analiza Jutarnjeg lista i Večernjeg lista, Medijske studije, 5 (2014) 10, 51-66, 54.

${ }^{51}$ Usp. James E. MURPHY, Press responsibility and new journalism, Journal of communication inquiry, 3 (1978) 2, 27-36, 32-33.

${ }^{52}$ Usp. Michael KUNCZIK, Astrid ZIPFEL, Uvod u znanost o medijima i komunikologiji, Zagreb, Zaklada Friedrich Ebert, 2006, 129.

${ }^{53}$ Pod imenovanim ili jasno identificiranim izvorima podrazumijevamo napisano ime i prezime ili inicijale osobe, ime medijske agencije, institucije, državne službe, ministarstva, novine, udruge, službeni dokument čiji je naziv napisan, policijske postaje, bolnice, popis stanovništva $\mathrm{s}$ napisanom godinom objave.

${ }^{54}$ Neimenovani izvori su anonimne osobe, visoki dužnosnici čije se ime ne spominje, agencije, udruge i institucije bez imena, podaci uz koje ne piše točan naziv agencije ili institucije koja je provela istraživanje.
} 
naka bilo je prikazano i više strana kao temelj pluralnosti informacija. Značajna odstupanja ne postoje ni u navođenju više izvora u člancima objavljenim u dvije preostale novine. Tako se u 30,6 \% objava medijski djelatnici Večernjeg lista oslanjaju na tri ili više izvora, no u petini od ukupnog broja objava ne navode niti jedan izvor, što je suprotno temeljnim postulatima struke, slično kao i u 24sata u kojem se u više od četvrtine objava (26,1 \%) ne navodi niti jedan izvor. Smatramo da je »bijeg « k jednom ili nijednom izvoru u objavi uzrokovan krizom u novinarstvu, koja je vrijeme, senzacionalizam i brzinu reprodukcije sadržaja stavila ispred kvalitete uradaka, što u konačnici rezultira i time da novinari teže sadržaju koji je lako pronaći, proslijediti i urediti. ${ }^{55}$ Stoga, rezultati prikazani na grafikonima slike broj 2 pokazuju da medijski djelatnici profesionalno zakazuju i kad je riječ o pozivanju na izvore i prikazivanju više različitih strana o nekoj temi te imenovanjem svojih izvora jer su u 46,8 \% slučajeva oni potpuno ili djelomično oslanjaju na neimenovane izvore (ili ih je bilo teško prepoznati) za koje se ne može utvrditi, postoje li uistinu.
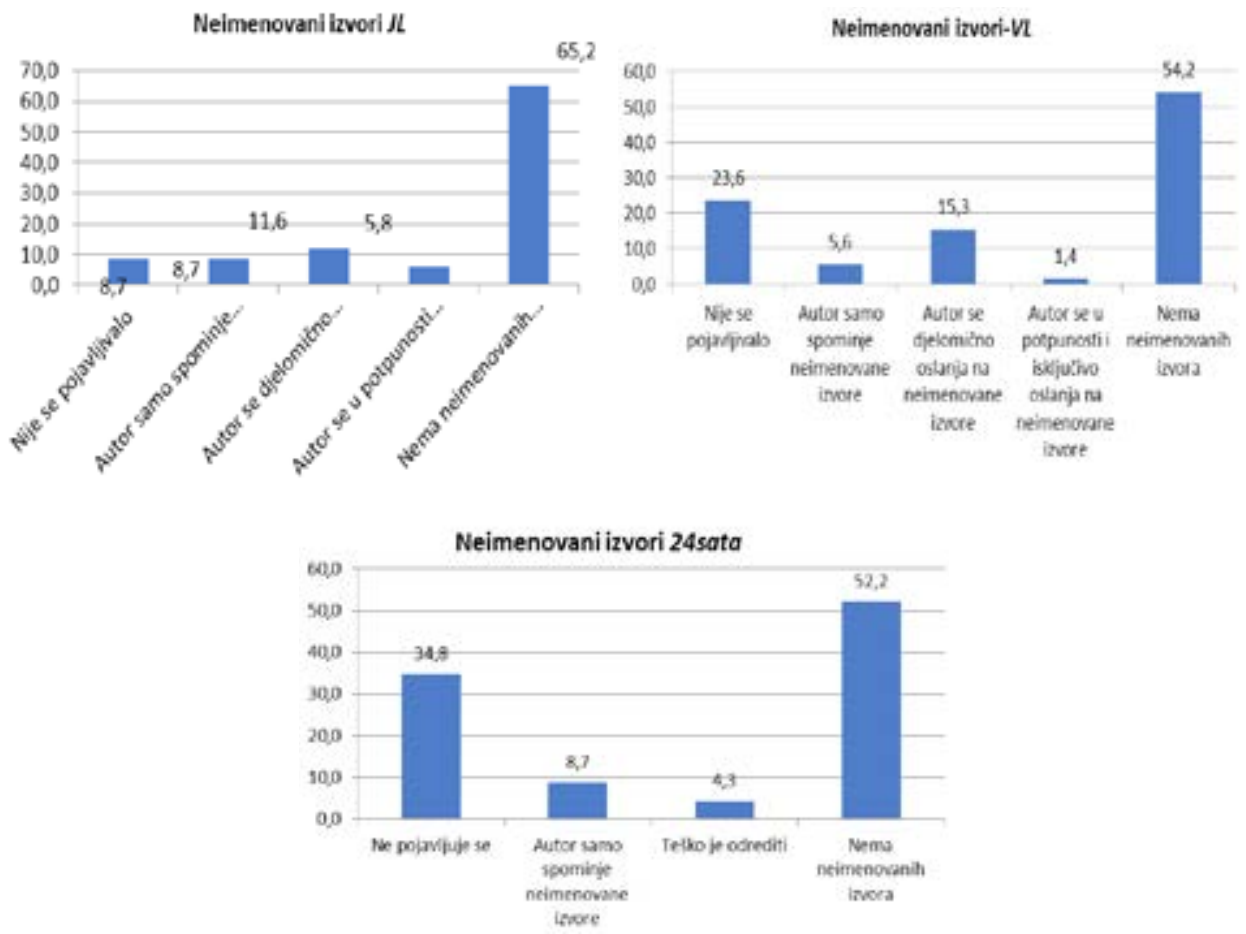

Slika 2. Neimenovani izvori N(\%)=164

\footnotetext{
${ }^{55}$ Usp. Lynette SHERIDAN BURNS, Understanding journalism, New Delhi, Sage Publications, 2002, 9.
} 


\subsection{Naslovi na naslovnicama i unutar dnevnih novina}

Cilj je novinskih naslova pružiti kratku i jasnu informaciju o sadržaju teksta. Budući da je naslov dio opreme članka koji privlači pozornost, a zatim i interes čitatelja na daljnje čitanje ostatka teksta, naslovi jesu »atraktivna platforma za kreiranje senzacionalističkih udica «. ${ }^{56}$ Takav pristup očituje se, među ostalim, i u subjektivnom izvještavanju, neutemeljenosti teksta i objavljenih podataka, neujednačenosti, krivoj interpretaciji podataka, kršenju etičkih pravila zadiranjem u privatni život, vrijeđanjem ljudskog dostojanstva i slično.

Uzevši u obzir navedeno, početna je pretpostavka bila da će u analiziranim novinskim prilozima biti primijećen senzacionalistički pristup. Međutim, rezultati istraživanja ne potvrđuju našu početnu hipotezu jer je u Jutarnjem listu ${ }^{57} \mathrm{i}$ Večernjem listu ${ }^{58}$ gotovo $85 \%$ informativnih naslova, a nešto više od $15 \%$ njih kritičkih. Kao primjer kritičkog naslova navodimo članak objavljen 20. rujna 2015. godine, autorice Tanje Rudež, u kojem izravno navodi citat Siniše Malaševića: »Hrvatska ne treba dizati vojsku jer na taj način samo širi nepotrebnu paniku.« U $24 \mathrm{sata}^{59}$ jednak je broj informativnih naslova, no manji je broj kritičkih, a pojavljuje se i $9 \%$ naslova koji su određeni kao senzacionalistički, poput naslova: »Može li jadnije? Ni izbjeglice ne žele biti u Hrvatskoj«, objavljenog 14. veljače 2017. godine. Odnos naslova i sadržaja najavljenog članka neujednačen je, odnosno, senzacionalističkim se naslovom želi privući pozornost čitatelja, dok podaci navedeni u tekstu tome naslovu ne odgovaraju: oni pružaju informacije građanima o imigrantskoj krizi na području Republike Hrvatske.

S obzirom na navedene rezultate, zaključujemo da su medijski djelatnici, ipak više pozornosti pri medijskoj prezentaciji prolaska izbjeglica i migranata kroz Hrvatsku, pridavali informacijama, a manje senzacionalizmu u širem smislu pojmovnog određenja.

\section{Zaključak}

Nakon provedenoga kvantitativnog istraživanja u kojemu je istraživano kako su i koliko hrvatske dnevne novine - Jutarnji list, Večernji list i 24sata - izvještavale o izbjegličkom valu i prolasku izbjeglica preko teritorija Republike Hrvatske, odbačene su sve naše polazne hipoteze. Premda su analizirane objave pokazale

\footnotetext{
${ }^{56}$ Katarzyna MOLEK-KOZAKOWSKA, Towards a pragma-linguistic framework for the study of sensationalism in news headlines, Discourse E Communication, 7 (2013) 2, 173-197, 177.

${ }^{57}$ Od 69 analiziranih članaka iz Jutarnjeg lista, 82,6 \% naslova je informativnog karaktera, a 17,4 $\%$ je kritičkih.

${ }^{58}$ Informativnog karaktera je 84,7 \% naslova članaka i podudaraju se s onim što je napisano u tekstu, dok je $15,3 \%$ naslova kritičkih.

${ }^{59}$ Informativno je 87 \% naslova. Za razliku od Jutarnjeg lista i Večernjeg lista, u 24sata primjetan je i senzacionalistički tip naslova u 8,7 \% i on čini veći postotak od kritičkih kojih ima $4,3 \%$.
} 
da su hrvatske novine u istraživanome razdoblju više pozornosti posvećivale informacijama i informativnim novinarskim vrstama, a manje senzacionalizmu, u medijskim objavama u kojima su glavni akteri bila djeca, primjetan je senzacionalizam, odnosno sudbina djece izbjeglica koristila se za privlačenje pozornosti čitatelja. Unatoč prije provedenim istraživanjima koja pokazuju netrpeljivost i strah od izbjeglica u hrvatskome društvu (i europskim društvima), našim istraživanjem napisa u hrvatskim dnevnim listovima nisu potvrđene hipoteze da se izbjeglice prikazuju kao prijetnja gospodarskoj stabilnosti Republike Hrvatske, kao ni da novinski napisi povezuju izbjeglice s ekstremističkim i terorističkim skupinama. Takav prikaz migranata pronađen je u samo četiri objave. Većina objava informirala je o prolasku izbjeglica kroz našu zemlju, odnosno kontroli graničnih prijelaza, dok je tek u malom broju objava riječ dana samim izbjeglicama i njihovim sudbinama, kao i pomoći koju su im građani i udruge pružale. $\mathrm{U}$ istraživanju su uočeni i propusti analiziranih medija u odnosu na vjerodostojnost objava jer se u većini napisa o migrantima i izbjeglicama koristio samo jedan izvor ili izvori uopće nisu bili navedeni. Takvo jednostrano informiranje nije samo profesionalan propust, već i propust u odnosu na osjetljivu društvenu problematiku i skupinu.

Smatramo da bi ovaj naš rad mogao biti polazište za daljnja istraživanja o izvještavanju o izbjeglicama i emigrantima u Republici Hrvatskoj. Budući da se većina mladih informira i oblikuje svoje stavove prema informacijama koje dobiva na internetu i društvenim mrežama, ${ }^{60}$ čini nam se važnim i vrijednim istražiti i objave na društvenim mrežama i komentare čitatelja vezane uz emigrante i izbjeglice s posebnim naglaskom na lažne vijesti koje se šire društvenim mrežama ${ }^{61}$ o izbjegličkoj tematici. U tome kontekstu nam se čini važnim i promicanje medijske pismenosti među mladima, ali i organiziranje radionica za obrazovanje novinara o izbjegličkoj i migrantskoj problematici, koja je aktualna kako na području Europske unije tako i u drugim dijelovima svijeta. S obzirom da se većina stanovnika Republike Hrvatske izjašnjava katolicima, ${ }^{62}$ vrijedno bi bilo istražiti i koliko odjeka u medijima imaju četiri glagola: primiti, zaštititi, promicati i integrirati; koja u vezi s izbjegličkom i migrantskom problematikom preporučuje papa Franjo. ${ }^{63}$

${ }^{60}$ Usp. Dominacija interneta sve veća, (04.04.2017), http://www.poslovni.hr/tehnologija/ dominacija-interneta-sve-veca-326321 (08.12.2018).

${ }^{61}$ Usp. How fake images spread racist stereotypes about migrants across the globe (01.05.2018); https://observers.france24.com/en/20180105-fake-images-racist-stereotypes-migrants?f bclid=IwAR0tJ4TLC6vGSfRzNC9G21YwyKWwX5xqk7MgCv9sE_pJ5n2RrJ6haWLZmJ0, (08.12.2018).

${ }^{62}$ Popis stanovništva, kućanstava i stanova 2011. godine, Državni zavod za statistiku, (25.04.2016), http://www.dzs.hr/Hrv/ censuses/census2011/results/htm/H01_01_12/ H01_01_12.html, (08.12.2018).

${ }^{63}$ Poruka pape Franje za Svjetski dan selilaca i izbjeglica 2018. Primiti, zaštititi, promicati $i$ integrirati migrante i izbjeglice, (25.08.2017); http://www.zg-nadbiskupija.hr/dokumenti/rijecsvetog-oca/primiti-zastititi-promicati-i-integrirati-migrante-i-izbjeglice, (08.12.2018). 


\section{Suzana Peran* - Anđelka Raguž*** \\ Media Coverage of Refugee Transit Through the Republic of Croatia \\ Summary}

The objective of this investigation was to determine the extent and nature of the coverage by three Croatian daily newspapers, Jutarnji list, Večernji list and 24sata, regarding the wave of refugees and refugee transit through the Republic of Croatia from September 2015 to April 2017.The initial hypothesis was that the coverage of the refugees was sensationalistic, and that refugees, immigrants and migrants were being portrayed as detrimental to the country's economic stability and potential terrorism threats, while newspaper articles were appealing to readers' emotions. We also examined the nature of the reporting, journalists' attitudes, eventual stereotyping of refugees, as well as possible violations of the ethical norms of journalism. The relationship between the headlines and texts was subjected to particular scrutiny. In the final section, we present our results and an analysis of the empirical findings. In the conclusion, we stress the importance of correlating our results with those other recent studies, especially investigations focusing upon social networking sites and the false information spread by such sites on the issue of refugees and migrants.

Key words: refugees, migrants, immigrants, media, Croatian daily newspapers.

(na engl. prev. Margaret Vuko)

* Suzana Peran, PhD, Catholic University of Croatia; Address: Hrvatsko katoličko sveučilište, Ilica 242, HR-10000 Zagreb, Croatia; E-mail: suzana.peran@unicath.hr.

** Anđelka Raguž, MA in journalism, University of Zagreb, Centre for Croatian Studies; Address: Hrvatski studiji, Borongajska cesta 83d, HR-10000 Zagreb, Croatia; E-mail: anraguz@hrstud.hr. 